\title{
Clinical Characteristics of Infectious Mononucleosis: A Retrospective Study
}

\author{
Keon-Ho Kim, Hee Jeong Kang, Song Jae Lee, Chang Myeon Song, Yong Bae Ji, and Kyung Tae (D) \\ Department of Otorhinolaryngology-Head and Neck Surgery, College of Medicine, Hanyang University, Seoul, Korea
}

\author{
전염성 단핵구증의 임상 특성: 후향적 분석 연구 \\ 김건호 · 강희정 · 이송재 · 송창면 · 지용배 · 태 경 \\ 한양대학교 의과대학 이비인후-두경부외과학교실
}

\author{
Received February 28, 2019 \\ Revised May 19, 2019 \\ Accepted May 21, 2019 \\ Address for correspondence \\ Kyung Tae, MD, PhD \\ Department of Otolaryngology- \\ Head and Neck Surgery, \\ College of Medicine, \\ Hanyang University, \\ 222 Wangsimni-ro, Seongdong-gu, \\ Seoul 04763, Korea \\ Tel $+82-2-2290-8585$ \\ Fax $+82-2-2293-3335$ \\ E-mail kytae@hanyang.ac.kr
}

Background and Objectives Infectious mononucleosis is mainly caused by Epstein-Barr virus infection and it presents sore throat, fever, tonsillar enlargement with exudate, cervical lymphadenopathy, hepatosplenomegaly, and etc. Therefore, it is often misdiagnosed with acute tonsillitis. The aim of this study was to evaluate the clinical characteristics of patients with infectious mononucleosis and recent changes.

Subjects and Method From January 2008 to December 2017, we retrospectively studied 83 patients who were diagnosed with infectious mononucleosis. We evaluated the patients' clinical characteristics such as sex, age, onset of disease, the department first visited, period of hospital stay, symptoms, signs, the results of serologic test, and complications.

Results Among 83 patients, 41 were male and 42 were female. The mean age was $16.1 \pm 7.28$, with the oldest patient being 38 years old and the youngest patient being 2 years old. The proportion of patients older than 25 years was $10.8 \%$. The most common symptom was sore throat (77\%), followed by fever (67\%), upper respiratory infection symptoms such as cough, sputum, rhinorrhea $(37 \%)$, abdominal pain $(16 \%)$, neck mass or neck pain $(13 \%)$, and headache $(4 \%)$. The most common sign was tonsillar enlargement $(85 \%)$, followed by tonsillar white patch (68\%), hepatosplenomegaly (67\%), and cervical lymphadenopathy (60\%). Complication occurred in 2 patients with mild jaundice, and there was no critical complication. The department patients first visited was mostly otolaryngology $(61 \%)$, followed by pediatrics $(21 \%)$, gastroenterology $(9 \%)$, and others $(6 \%)$.

Conclusion Patients with infectious mononucleosis mostly appeared to have fever, pharyngitis or cervical lymphadenitis, and the complication rate was low. The primary infection age of infectious mononucleosis tended to increase in recent years. In adult patients, cervical lymphadenitis was less, and white blood cell count and the proportion of lymphocyte was lower compared to pediatric patients.

Korean J Otorhinolaryngol-Head Neck Surg 2019;62(11):642-6

\section{서 론}

전염성 단핵구증(Infectious mononucleosis)은 엡스테인바 바이러스(Epstein-Barr virus, EBV) 감염에 의해 발생하
는 질환으로, 인후통, 발열, 편도비대, 경부 림프절 종대 및 동통, 간 및 비장 비대 등의 임상증상 및 징후를 보이는 질환 이다. 일반적인 급성 편도염과 임상증상이 매우 유사하기 때문에 의사들이 주의 깊게 보지 않으면 놓칠 가능성이 큰

This is an Open Access article distributed under the terms of the Creative Commons Attribution Non-Commercial License (https:/creativecommons.org/licenses/by-nc/4.0) which permits unrestricted non-commercial use, distribution, and reproduction in any medium, provided the original work is properly cited. 
질환이며, 대부분의 전염성 단핵구증이 양호한 예후를 보이 지만 드물게 재발 혹은 만성화하거나 치명적인 합병증으로 생명에 지장을 초래하는 경우도 있다. ${ }^{23)}$ 또한 $\mathrm{EBV}$ 의 초감염 연령이 점차 높아지고 있어, 이전에는 소아 및 청소년에서 흔 한 질환이었지만 최근에는 성인에서도 발생하는 등 예전에 비해 그 임상양상이 변화하고 있다. ${ }^{4)}$

이에 저자들은 전염성 단핵구증으로 진단되고 치료받았던 환자들을 대상으로 임상적 특성을 알아보고 최근의 변화양 상에 대하여 분석하여 향후 진단 및 치료에 도움을 주고자 본 연구를 시행하였다.

\section{대상 및 방법}

2008년 1월부터 2017년 12월까지 한양대학교병원에서 전염 성 단핵구증으로 진단받고 치료받았던 환자 83예를 대상으 로 의무기록을 후향적으로 조사분석하였다. 5 가지 증상 또는 징후(발열, 인후통, 경부 림프절 비대, 편도 비대, 간효소 수 치 상승) 중 3 가지 이상을 나타내는 환자에서 $\mathrm{EBV}$ 혈청 항 체검사를 시행하였고, 이 중 EBV viral capsid antigen(VCA) immunoglobulin $\mathrm{M}(\mathrm{IgM})$ 양성 혹은 EBV early antigen(EA) $\mathrm{IgM}$ 양성 소견을 보인 환자들을 전염성 단핵구증으로 진단 하였다. 환자들의 성별, 진단 당시 연령, 입원 기간, 증상 및 징후, 혈액검사 결과, 합병증 유무 등을 조사하였으며, 이전 연구들의 결과와도 비교분석하였다. 증상이나 병력상 전염성 단핵구증이 강하게 의심되지만 혈액검사에서 $\mathrm{EBV} \operatorname{IgM}$ 음 성이었던 경우는 연구에서 제외하였으며, 환자의 의무기록이 불충분했던 경우도 연구에서 제외하였다(IRB No. 201807-002).

\section{결 과}

대상 환자 83명 중 남성은 41명(49.4\%), 여성은 42명(50.6\%) 이었으며, 내원 당시 평균 나이는 16.1세( \pm 7.28 세)였다(Table 1). 가장 나이가 많았던 환자는 38 세였고, 가장 어렸던 환자는 2세였다. 연령군으로 보았을 때 16 20세 사이가 34명(41.0\%) 으로 가장 많았으며, 10 세 이하의 유소아군이 18 명(21.7\%)이 였다(Fig. 1).

임상증상으로는 인후통이 64명(77.1\%), 발열이 56명(67.5\%), 감기증상(기침, 가래, 콧물, 코막힘)이 31명(37.4\%)에서 나타 났다. 그 밖에 복통이 14 명(16.9\%), 경부 종물 또는 통증이 11명(13.3\%), 두통이 4명(4.8\%)에서 나타났다.

신체검사 결과로 구개편도 비대가 71 명(85.5\%)에서 있었으 며 편도의 삼출막이 동반된 경우는 57 명(68.7\%)에서 관찰되
었다. 그 외에 간과 비장 비대는 56명(67.5\%), 경부 림프절 종 대 및 동통은 50명(60.2\%)에서 관찰되었다.

혈액검사 결과에서는 총 백혈구 수가 10000 이상인 경우 가 47명(56.6\%)이었으며, 그 중 림프구분율이 $50 \%$ 이상인 환 자는 49 명(59.0\%)이었고, 비정형 림프구분율이 $1 \%$ 이상인 환 자는 36명(52.2\%)이었다. 간 효소(aspartate aminotransferase, AST; alanine aminotransferase, ALT) 수치 증가는 66 명(79.5\%)에서 관찰되었다.

$\mathrm{EBV}$ 감염 시 가장 먼저 증가되는 것으로 알려져 있는 $\mathrm{EBV}$ $\mathrm{VCA} \operatorname{IgM}$ 은 77 명(92.8\%)의 환자에서 양성 소견을 보였으며, EBV EA IgM은 15명(18.1\%)에서 양성이었다.

합병증으로는 2 명 $(2.4 \%)$ 의 환자에서 경도의 황달이 발생 하였고, 다른 치명적인 합병증은 없었다.

전체 환자 중 51명(61.4\%)의 환자는 이비인후과로 처음 내 원하였고, 그 다음으로 18 명(21.6\%)은 소아청소년과, 8 명

Table 1. Demographics and clinical characteristics of patients with infectious mononucleosis

\begin{tabular}{|c|c|}
\hline Variables & $\mathrm{n}(\%)$ \\
\hline \multicolumn{2}{|l|}{ Sex } \\
\hline Male & $41(49.4)$ \\
\hline Female & $42(50.6)$ \\
\hline Ages (year) & $16.1 \pm 7.28$ \\
\hline \multicolumn{2}{|l|}{ Symptoms } \\
\hline Sore throat & $64(77.1)$ \\
\hline Fever & $56(67.5)$ \\
\hline Cough/sputum/rhinorrhea/nasal obstruction & $31(37.4)$ \\
\hline Neck mass or neck pain & $11(13.3)$ \\
\hline Headache & $4(4.8)$ \\
\hline Abdominal pain & $14(16.9)$ \\
\hline \multicolumn{2}{|l|}{ Physical exam } \\
\hline Tonsillar enlargement & $71(85.5)$ \\
\hline Tonsillar whitish patch & $57(68.7)$ \\
\hline Hepatosplenomegaly & $56(67.5)$ \\
\hline Cervical lymphadenopathy & $50(60.2)$ \\
\hline \multicolumn{2}{|l|}{ Serology test } \\
\hline Leukocytosis (WBC >10000) & $47(56.6)$ \\
\hline Lymphocytosis (lymphocyte>50\%) & $49(59.0)$ \\
\hline Elevated atypical lymphocyte $(>1 \%)$ & $36(52.2)$ \\
\hline Elevated LFT (AST or ALT>50) & $66(79.5)$ \\
\hline EBV VCA IgM (+) & $77(92.8)$ \\
\hline EBV EA IgM (+) & $15(18.1)$ \\
\hline \multicolumn{2}{|l|}{ Complication } \\
\hline None & $81(97.6)$ \\
\hline Jaundice & $2(2.4)$ \\
\hline
\end{tabular}

WBC: white blood cell, LFT: liver function test, AST: aspartate aminotransferase, ALT: alanine aminotransferase, EBV: EpsteinBarr virus, VCA: viral capsid antigen, EA: early antigen, IgM: immunoglobulin $M$ 


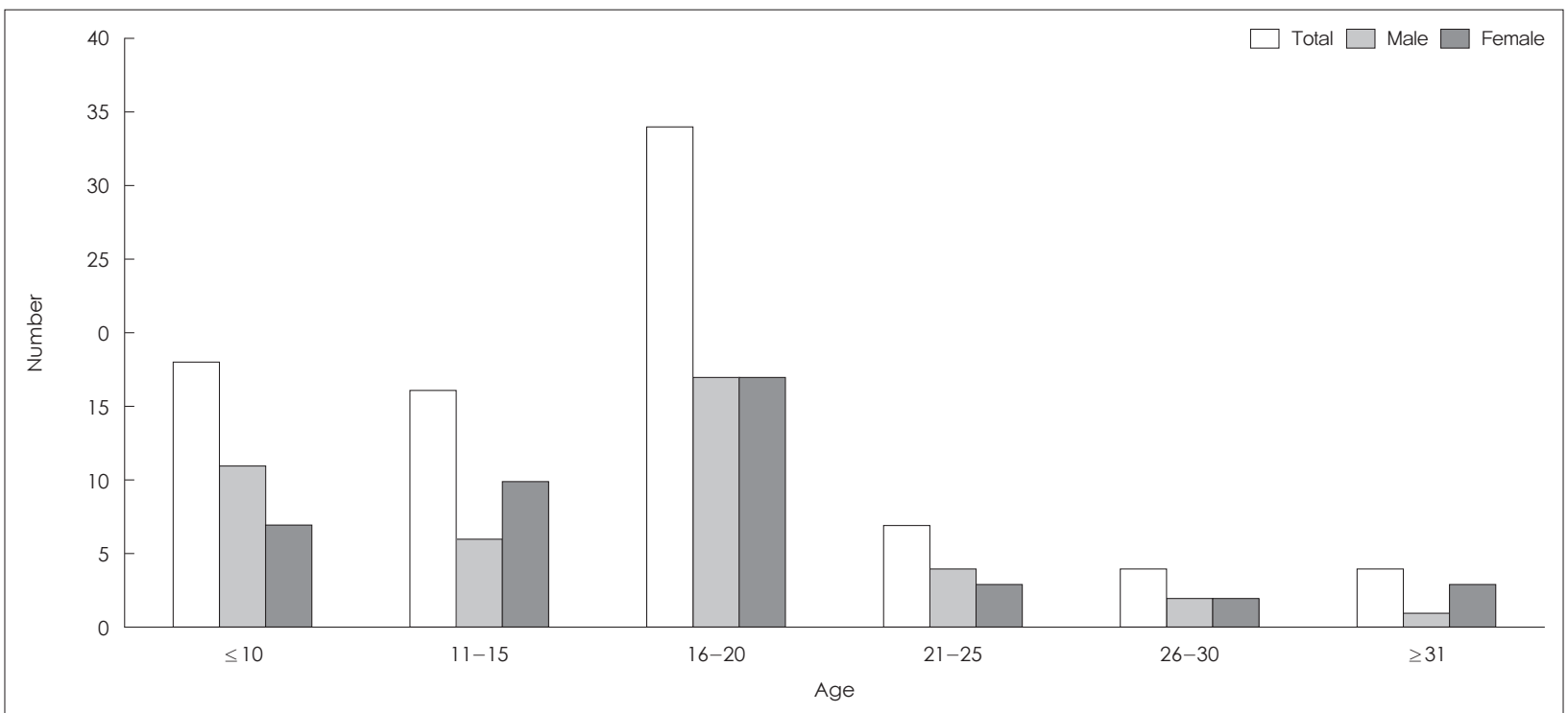

Fig. 1. Distribution of patients with infectious mononucleosis according to age.

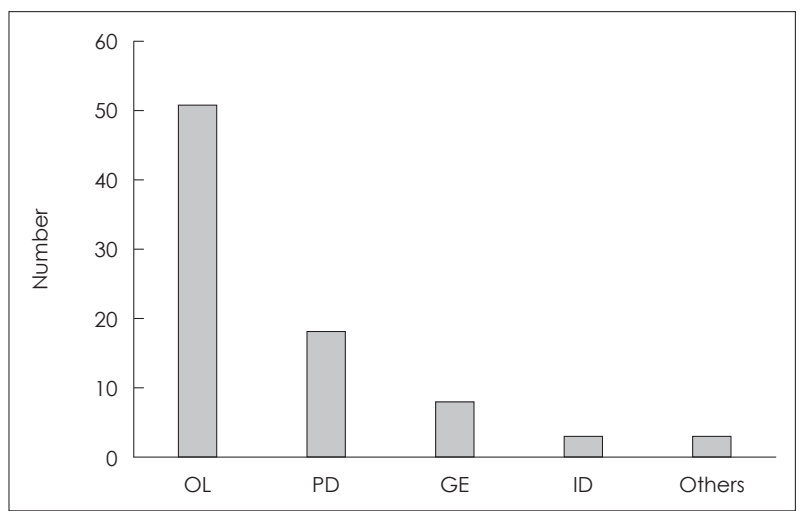

Fig. 2. Distribution of the department that patients with infectious mononucleosis visited first. OL: otolaryngology, PD: pediatrics, GE: gastroenterology, ID: infectious department.

(9.6\%)은 소화기내과로 내원하였다(Fig. 2). 이외 감염내과 3 명(3.6\%), 류마티스내과 2명(2.4\%), 산부인과 1명(1.2\%)순이었 다. 소화기내과로 입원했던 환자 중 4명은 입원 치료 도중 타 과로 전과되었는데, 3 명은 감염내과로, 1 명은 이비인후과로 전 과되었다. 산부인과로 내원했던 1명은 류마티스내과로 전과 되어 치료받았다.

Pearson 상관계수를 이용하여 초감염 나이에 따른 임상 양상의 차이를 비교해 보았을 때, 나이가 증가함에 따라 혈 액검사 결과 중 $\mathrm{ALT}$ 수치는 유의하게 증가하였고( $p=0.02)$, 총 백혈구 수와 림프구분율, 비정형 림프구분율 수치는 유의 하게 감소하였다 $(p=0.005,0.045,0.013)$. 또한, 나이가 증가 함에 따라 증상 발생일로부터 내원일까지의 기간은 유의하 게 증가하였고 $(p=0.008)$, 경부 림프절 종대의 소견을 보이는 비율은 유의하게 감소하였다 $(p=0.013)$. 그 외에 입원 기간, 증
상, 징후, 혈액검사 결과는 유의한 상관관계가 없었다(Table 2 and 3).

\section{고 찰}

전염성 단핵구증은 $\mathrm{EBV}$ 감염의 의해 발생하는 질환으로, 대표적인 임상증상 및 징후로 인후통, 발열, 삼출물을 동반 한 편도 비대, 경부 림프절 종대 혹은 간과 비장 비대를 보인 다. 혈액검사 결과 중에서는 간 효소 수치 증가, $\mathrm{EBV} \mathrm{VCA}$ $\mathrm{IgM}$ 양성 소견이 대부분의 환자에서 나타난다. ${ }^{5)}$ Choi 등이이 대한이비인후과학회지에 발표한 연구에서는 인후통 $76.4 \%$, 편도 비대 $88.2 \%$, 편도 삼출물 $58.9 \%$, 경부 림프절 종대가 $76.4 \%$ 에서 나타났고 이는 본 연구와 비슷하였다. 차이가 있 는 항목으로는 Choi 등 ${ }^{6}$ 의 연구에서는 발열증상이 $94.1 \%$ 로 거의 모든 환자에서 나타났으나 본 연구에서는 $67.5 \%$ 에서 있었다. 이는 본 연구에 전형적인 증상을 보이지 않았던 성인 들이 더 많이 포함된 것과 연관이 있으리라 추정된다.

본 연구에서 임상증상으로 인후통, 경부 통증 등 이비인후 과와 관련된 증상들이 많아 환자들이 이비인후과로 처음 내 원한 것으로 생각되며, 유소아들은 소아청소년과로, 복통이 동반된 환자들은 소화기내과로 각각 방문하였으며, 입원 이후 에는 전과 또는 협진을 통하여 여러 과들이 함께 치료 계획 을 논의하였다. 이전 연구들에서는 방문한 과에 대한 분석은 없었으며, 연구자의 소속에 따라 이비인후과 혹은 소아청소 년과로 내원했던 환자들을 표본으로 선정하여 연구를 진행 하였다. ${ }^{7)}$

전체 환자 중 초감염 연령이 25세 이상인 비율은 본 연구에 
Table 2. Correlations between primary infection age and serology tests

\begin{tabular}{lcccccccc}
\hline & WBC & Lymphocyte & $\begin{array}{c}\text { Atypical } \\
\text { lymphocyte }\end{array}$ & Monocyte & PLT & AST & ALT \\
\hline Age & & & & & & & & \\
$\quad$ Pearson correlation coefficient & -0.307 & -0.222 & -0.297 & 0.023 & -0.004 & 0.211 & 0.256 \\
$\quad$-value & $0.005^{*}$ & $0.045^{*}$ & $0.013^{*}$ & 0.834 & 0.970 & 0.056 & $0.020^{*}$ \\
\hline
\end{tabular}

$* p<0.05$. WBC: white blood cell, PLT: platelet, AST: aspartate aminotransferase, ALT: alanine aminotransferase

Table 3. Correlations between primary infection age and onset of disease, period of hospital stay, symptoms and signs

\begin{tabular}{lccccccc}
\hline & Onset & $\begin{array}{c}\text { Hospital } \\
\text { periods }\end{array}$ & $\begin{array}{c}\text { Tonsillar } \\
\text { enlargement }\end{array}$ & $\begin{array}{c}\text { Tonsillar white } \\
\text { patch }\end{array}$ & $\begin{array}{c}\text { Hepato- } \\
\text { splenomegaly }\end{array}$ & Cervical LAP & Fever \\
\hline Age & & & & & & & \\
$\quad$ Pearson correlation coefficient & 0.291 & 0.116 & -0.069 & 0.072 & 0.036 & -0.272 & -0.042 \\
$\quad \begin{array}{l}\text { p-value } \\
* p<0 \text {.05. LAP: lymphadenopathy }\end{array}$ & $0.008^{*}$ & 0.298 & 0.536 & 0.517 & 0.744 & $0.013^{*}$ & 0.708 \\
\hline
\end{tabular}

서 9명(10.8\%)이었다. Davidson ${ }^{8}$ 이 1960년대에 환자 8258명 을 대상으로 조사했던 연구에서는 25세 이상인 경우가 $8.1 \%$ 였 고, Caldwell과 Heath"가 가 1974년부터 1976년 사이의 환자 1258 명을 대상으로 했던 연구에서는 $8.7 \%$ 로 본 연구와 비교 했을 때 유의한 차이는 없지만 초감염 연령이 과거에 비해 점차 높아지는 경향을 발견할 수 있었다. 유의한 차이를 보이 지 않았던 이유로는 본 연구의 표본 수가 비교적 적고, 소아 청소년과에서 입원치료를 받았던 유소아들이 타 연구에 비해 많이 포함되었기 때문으로 생각할 수 있다. 국내의 연구로는 Choi 등이 대한이비인후과학회지에 발표한 연구에서 20세 이상 비율이 $5 \%$ 인데 비해 본 연구에서는 $22.9 \%$ 로 4 배 이상 높은 수치를 보였으며, Son과 Shin이 대한소아과학회지에 발표한 연구에서는 18 세 이하의 환자들을 대상으로 하였는 데, 이들의 평균 연령은 6.17 세였다. 본 연구에서 18 세 이하의 환자들의 평균 나이는 12.23 세로, 소아 연령군에서의 초감염 나이가 2배 가까이 증가하였음을 알 수 있었다.

전염성 단핵구증 환자에서 나이가 어릴수록 발열, 인후염, 림프절 종대의 3 대 징후가 대부분에서 나타나며, 나이가 증 가할수록 이 중 단 한 가지 징후만 보여 조기 진단이 어려운 경우가 많다. ${ }^{10)}$ 본 연구에서도 나이가 증가할수록 경부 림프 절 종대 비율이 유의하게 감소하였고, 총 백혈구 수와 림프 구분율, 비정형 림프구분율 수치도 유의하게 감소하였다.11) 이 는 성인에서 소아에 비해 전형적인 징후나 혈액검사 소견을 보이지 않는 경우가 많다는 뜻으로 해석할 수 있다. 반면 ALT 수치는 나이가 증가할수록 유의하게 증가하였는데, 이는 성 인과 소아의 알코올 섭취량 차이 등의 이유라 추측할 수도 있다.7) 본 연구와 이전의 연구에서도 증상 발생일로부터 내원 일까지의 기간도 나이가 증가할수록 유의하게 증가하였는데, 이는 성인들이 대부분 직업상의 이유로 증상 초기에는 병원 을 내원하지 않다가 추후 증상 호전이 없거나 악화되었을 때
비로소 병원을 찾기 때문으로 볼 수 있다. ${ }^{6,12}$

전염성 단핵구증의 합병증은 $5 \%$ 미만에서 나타나는 것으 로 알려져 있으며, 황달, 뇌수막염, 용혈성 빈혈, 비장 파열, 다 발성 경화증 등 다양한 양상의 합병증이 발생할 수 있다.13,14) 본 연구에서는 2 명의 환자에서 경도의 황달이 발생하였으며 다른 치명적인 합병증은 발견되지 않았다. ${ }^{15)}$ 하지만 Salazard 등히이 발표한 논문에서처럼 드물게 상기도 폐쇄 등 응급처 치를 요하는 합병증도 보고되고 있어 항상 주의를 기울여야 할 것으로 사료된다.

전염성 단핵구증의 치료에서 항생제의 사용은 필수는 아 니며, 이차적인 세균감염을 막기 위한 목적으로 사용할 수 있 는데, 항생제 중 ampicillin 계열을 사용하면 전신 발진의 부 작용이 일어날 수 있다고 알려져 있다. 본 연구에서도 이차적 인 세균감염 예방을 위해 3세대 세팔로스포린 계열 항생제 를 사용하였고, ampicillin 계열의 항생제를 사용한 경우는 없었다. 또한 항생제 사용으로 전신 발진의 부작용을 보인 사례도 없었다.

본 연구의 주요 제한점은 10 년 동안 단일기관에서 진단받 고 치료받은 환자들만을 대상으로 하여, 연구 표본 수가 적다 는 점이다. 따라서 본 연구의 결과를 역학 연구의 관점에서 일 반화시키기에는 무리가 있으며, 이전의 연구들과 비교분석해 볼 때 성인에서의 발병률이 상승하고 있는 경향을 볼 수 있다 고 기술할 수 있다. 다른 제한점으로는 환자들이 퇴원 후에 병원을 재방문하지 않거나 짧은 외래 추적 관찰로 끝나는 경 우가 많아 합병증 발생률이 저평가되었을 가능성이 있다.

전염성 단핵구증은 대부분 어린 소아에서 $\mathrm{EBV}$ 에 의한 초 감염으로 발현하는 것으로 알려져 있으나, 최근 사회, 경제적 발달에 의해 초감염 연령이 높아지면서 성인에서도 발병하 는 비율이 증가하는 경향을 볼 수 있었으며, 발병 연령이 증 가할수록 전형적인 임상증상이나 징후를 보이지 않는 경우 
가 많았다.

\section{ORCID}

Kyung Tae

\section{REFERENCES}

1) Schwartzkopf J. Infectious mononucleosis. JAAPA: 2018;31(11):52-3.

2) Vogler K, Schmidt LS. [Clinical manifestations of Epstein-Barr virus infection in children and adolescents]. Ugeskr Laeger 2018;180(20): V09170644.

3) Lennon P, Crotty M, Fenton JE. Infectious mononucleosis. BMJ 2015;350:h1825.

4) Morris MC, Edmunds WJ. The changing epidemiology of infectious mononucleosis? J Infect 2002;45(2):107-9.

5) Zhang L, Zhou P, Meng Z, Pang C, Gong L, Zhang Q, et al. Infectious mononucleosis and hepatic function. Exp Ther Med 2018;15(3): 2901-9.

6) Choi JS, Kim TH, Park HY, Lim SC. Clinical analysis of infectious mononucleosis. Korean J Otorhinolaryngol-Head Neck Surg 1997; 40(6):914-21.

7) Son KH, Shin MY. Clinical features of Epstein-Barr virus-associated infectious mononucleosis in hospitalized Korean children. Korean J Pediatr 2011;54(10):409-13.

8) Davidson RJ. A survey of infectious mononucleosis in the NorthEast Regional Hospital board area of Scotland, 1960-9. J Hyg (Lond)

1970;68(3):393-400.

9) Caldwell GG, Heath CW Jr. Surveillance of infectious mononucleosis cases by use of existing data from state laboratories. Public Health Rep 1982;97(6):579-82.

10) Kim JH, Jang HJ, Yoon HY, Lee SI, Kwon JH, Jung JY, et al. Clinical features of hospitalized adults with infectious mononucleosis. Korean J Hematol 2005;40(1):1-7.

11) Wang Y, Li J, Ren YY, Zhao H. The levels of liver enzymes and atypical lymphocytes are higher in youth patients with infectious mononucleosis than in preschool children. Clin Mol Hepatol 2013; 19(4):382-8.

12) Nye FJ. Social class and infectious mononucleosis. J Hyg (Lond) 1973;71(1):145-9.

13) Cocuz ME, Idomir ME, Ticău OC. [Clinical and biological aspects of liver damage in infectious mononucleosis]. Bacteriol Virusol Parazitol Epidemiol 2003;48(2-3):177-81.

14) Siliézar MM, Muñoz CC, Solano-Iturri JD, Ortega-Comunian L, Mollejo M, Montes-Moreno S, et al. Spontaneously ruptured spleen samples in patients with infectious mononucleosis: Analysis of histology and lymphoid subpopulations. Am J Clin Pathol 2018; 150(4):310-17.

15) Valentini P, Angelone DF, Miceli Sopo S, Ngalikpima CJ, Ranno O. Cholestatic jaundice in infectious mononucleosis. Minerva Pediatr 2000;52(5-6):303-6.

16) Salazard B, Paut O, Nicollas R, Zandotti C, Chrestian MA, Thuret $\mathrm{I}$, et al. [Severe upper airway obstruction in infectious mononucleosis: A life emergency]. Arch Pediatr 2001;8(9):952-6. 